\title{
DETERMINANTS OF FORMATION AND DEVELOPMENT OF INTERNATIONAL e-COMMERCE
}

\section{ДЕТЕРМІНАНТИ ФОРМУВАННЯ І РОЗВИТКУ МІЖНАРОДНОӤ ЕЛЕКТРОННОЇ ТОРГІВЛІ}

\section{ДЕТЕРМИНАНТЫ МЕЖДУНАРОДНОЙ ЭЛЕКТРОННОЙ ТОРГОВЛИ}

\author{
Yatsenko O.M.
}

Doctor of Economics, Professor of Department of International Trade and Marketing Kyiv National Economic University named after Vadym Hetman. E-mail: yacenkoolgakneu@ gmail.com

\section{Dmytriyeva N.O.}

Senior lecturer Faculty of International Relations “KROK” University. E-mail: ndmitrik@ukr.net

\section{Яценко О.М.}

Доктор економічних наук, професор кафедри міжнародної торгівлі та маркетингу Київського національного економічного університету імені Вадима Гетьмана. E-mail: yacenkoolgakneu@gmail.com

Дмитрісва Н.О.

Старший викладач кафедри міжнародних економічних відносин Університету «КРОК». Е-mail: ndmitrik@ukr.net

\section{Яценко О.Н.}

Доктор экономических наук, профессор кафедры международной торговли и маркетинга Киевского национального экономического университета имени Вадима Гетьмана. E-mail: yacenkoolgakneu@gmail.com

Дмитриева Н. А.

Старший преподаватель кафедры международных экономических отношений Университета «КРОК». Еmail:ndmitrik@ukr.net

Abstract. In this article the authors have considered and summarized results of previous scientific studies as well as some actual events and issues of comprehensive evaluation of determinants and factors of influence in particular on the development of international or domestic e-commerce. With the use of the system analysis e-commerce activities have been considered as a result of interactions between endogenous and exogenous environmental factors. Exogenous determinants of the international electronic commerce include micro- and macroenvironmental determinants. The microenvironmental determinants define a system of relations among consumers, competitors, potential competitors including manufacturers of substitutes, suppliers and intermediators.

The macroenvironmental determinants are represented by economical, political and legal, scientific and technical, natural and social factors. Such an approach is a subject of our further scientific studies and it encourages the next stage of searches - research into the international aspects of institutional provisions for controlling international e-commerce activities.

Key words: digital economy, determinants, electronic (e-) business, electronic (e-) commerce, e-commerce, Internet, information and communication technologies, international electronic trade and economic activity.

Анотація. У даній статті авторами узагальнюються результати досліджень вчених попередників, а також окремі актуальні події та питання комплексного оцінювання окремих детермінант та факторів впливу, зокрема, на розвиток 
міжнародної чи національної е-торгівлі. Завдяки системному аналізу електронна торговельна діяльність розглянута як результат взаємодії факторів ендогенного та екзогенного середовища. Екзогенні детермінанти міжнародної електронної торгівлі включають детермінанти мікро- та макросередовища. Детермінанти мікросередовища визначають систему взаємовідносин із споживачами, конкурентами, потенційними конкурентами, у тому числі з виробниками субститутів, 3 постачальниками та посередниками. Детермінанти макросередовища представлені економічними, політико-правовими, науково-технічними, природними та соціальними факторами. Такий підхід є предметом наших подальших наукових досліджень $i$ спонукає до наступного пошукового етапу - дослідження міжнародних аспектів інституційного забезпечення регулювання міжнародної електронної торговельної діяльності.

Ключові слова: ичифрова економіка, детермінанти, фактори, електронний (е-) бізнес, електронна (е-) торгівля, електронна (е-) комериія, Інтернет, інформаційнокомунікаційні технології, міжнародна електронна торговельна діяльність.

Аннотация. В данной статье авторами обобщаются результаты исследований ученых предшественников, а также отдельные актуальные события и вопросы комплексной оценки отдельных детерминант и факторов воздействия, в частности, на развитие международной или наџиональной электронной торговли. Благодаря системному анализу международная электронная торговая деятельность рассмотрена как результат взаимодействия факторов эндогенной и экзогенной среды. Экзогенные детерминанты международной электронной торговли включают детерминанты микро- и макросреды. Детерминанты микросреды определяют систему взаимоотношений с потребителями, конкурентами, потенциальными конкурентами, в том числе с производителями субститутов, с поставщииками $и$ посредниками. Детерминанты макросреды представлены экономическими, политикоправовыми, научно-техническими, природныли и сочиальныли факторами. Такой подход является предметом наших дальнейших научных исследований и побуждает к следующему поисковому этапу - исследование международных аспектов институционального обеспечения регулирования международной электронной торговой деятельности.

Ключевые слова: иифрровая экономика, детерминант, факторы, электронный (е-) бизнес, электронная (е-) торговля, электронная (е-) коммерция, Интернет, информационно-коммуникачионные технологии, международная электронная торговая деятельность.

Statement of a problem. Until now the issues of a comprehensive evaluation of effects of some determinants and factors in particular on the development of international or national e-commerce have been disregarded by specialists. Therefore the theme of studies is topical due to necessity of determination of key determinants and a degree of their impact on innovative changes in the international e-commerce business systems. Analysis and accumulation of provisions for businesses in particular e-commerce business with proper production factors for improving international e-commerce activities is the main feature of these determinants. As it has been stated in the Project for International Hub of projects for sustainable development management, under the conditions of globalization the economic sovereignty (the rights for development) can only be maintained by developing the exogenous factor (determinant) that generates new forms of the economic genesis by expanding the space-time boundaries of the economy. According to the control theory if a system loses the exogenous factor (the dimension expanding factor) it is absorbed by another system. 
The article's goal is to determine major global determinants and evaluate impact factors for formation and development of international e-commerce activities.

Analysis of recent studies and publications. The study has been carried out on the basis of the fundamental works of the well-known economists: A. Giddens, P. Drucker, M. Castells, M. Porter, A. Toffler and others. The modern problems of the methodological principles of some determinants and factors that impact on the formation and development of international or national electronic business have become a subject of studies performed by a few native scientists and experts among whom there are O. Belova, O. Zozul'ov, N. Karas'oov, N. Kramorenko, A. Kudinov, K. Poltorak, O. Romanenko, I. Semeniuk, S. Sidenko, T. Shapovalov, O. Yatsenko and others.

Recognizing the achievements of domestic and foreign economists we note that these problems have not been solved definitively in Ukraine and without doubt some aspects of the problem demand more detailed scientific studies and this makes the theme of studies actual.

Presentation of the basic material of the study. On the one hand the global space of the Internet mirrors the trends of progressive informatization of the global economy development, on the other hand it is an active global factor of the development of international e-commerce. The term 'factor' is originated from a Latin word 'factor' (who/which acts) and in dictionaries it is explained as a stimulating force of a certain process or phenomenon; a motive force of a process that defines its nature; a feature or a group of causes united by a certain attribute [5, page 1526]. The term "influence" is also interpreted as a leading force of a process, a cause and also as a factor [5, page 1601]. So, in this study, in accordance with the above interpretation the terms "factor" and "influence" have the same meaning.

Generally the term "factor" is related with the term "determinant" (Lat. "determiner", to determine or to cause). The determinant is one who/which causes a causal relationship between some phenomena, it also means an ingredient, component, qualifier, cause, condition [5, page 289]. The term "determination" is a derivative term from the words "determinant", "to determine". Now the system determinacy of objective and subjective processes that take place in the sphere of international e-commerce businesses does not raise any doubts of researchers. Despite this complexity, the ambiguity and topicality of the determinacy processes have led to too wide use of these terms in the scientific community, in particular, by A. Kudinova [21, pages 14-25], O. Yatsenko [39, pages 66-100 ] and others.

Thus, there is no any common idea of contents of the terms "determinant" and "factor" and a few scientists have studied their use in relation to the development of e-commerce. In Ukraine this issue was studied in a number of scientific works [2, pages 235-240; 19, pages $351-358 ; 23$, pages $5-20 ; 24$, pages $5-17$; 28, pages $373-378 ; 30 ; 31$, pages $167-173 ; 38$, pages 131-134]. Taking into account that the meaning of terms "factor" and "determinant" is the same we do not distinguish them in this work. Therefore, the most important task is to define key determinants and a degree of their influence on innovation changes in the systems of international e-commerce business, whose general structure may be presented by a scheme depicted in Fig. 1.

In our opinion, now the number of factors increases significantly in particular the macroeconomic environmental factors, which define features, regularities and trends in development of a totally new kind of the international commerce - international e-commerce. Among these factors we can single out the most important ones that have stabilizing effects on the development of e-commerce business:

- macroeconomic factors: dynamics of the national production and consumption indices; level of the economy's monetization; stability of the economic situation; share of the shadow sector in the economy; size of the national economic complex; level of the economy's 
monopolization; the taxation and investment climate; level of price differentiation for homogenous products and development of means for e-payments; availability of convenient and relatively inexpensive ways of delivery goods to consumers;

- infrastructure factors: development of information technologies, first of all telecommunications; size and growth rates for Internet audience; level of intellectual potential in the sphere of developing computer technologies;

- control and legal factors: efficiency of corporate management; dynamism in perception of innovations by management; level of corruption; level of legal control over ecommerce;

- factors that determine the development of e-commerce: share of cash means in payments for supplied products; level of product unification - level of business process automation - level of development of network infrastructure; fragmentation of markets and level of competition; intensity of finance flows and export or import orientation; system organization for sales and supply activities; degree of provision with IT-staff; degree of utilization of Internet potentialities; level of investments into information technologies - level of management; character of mutual relations between managers and shareholders.

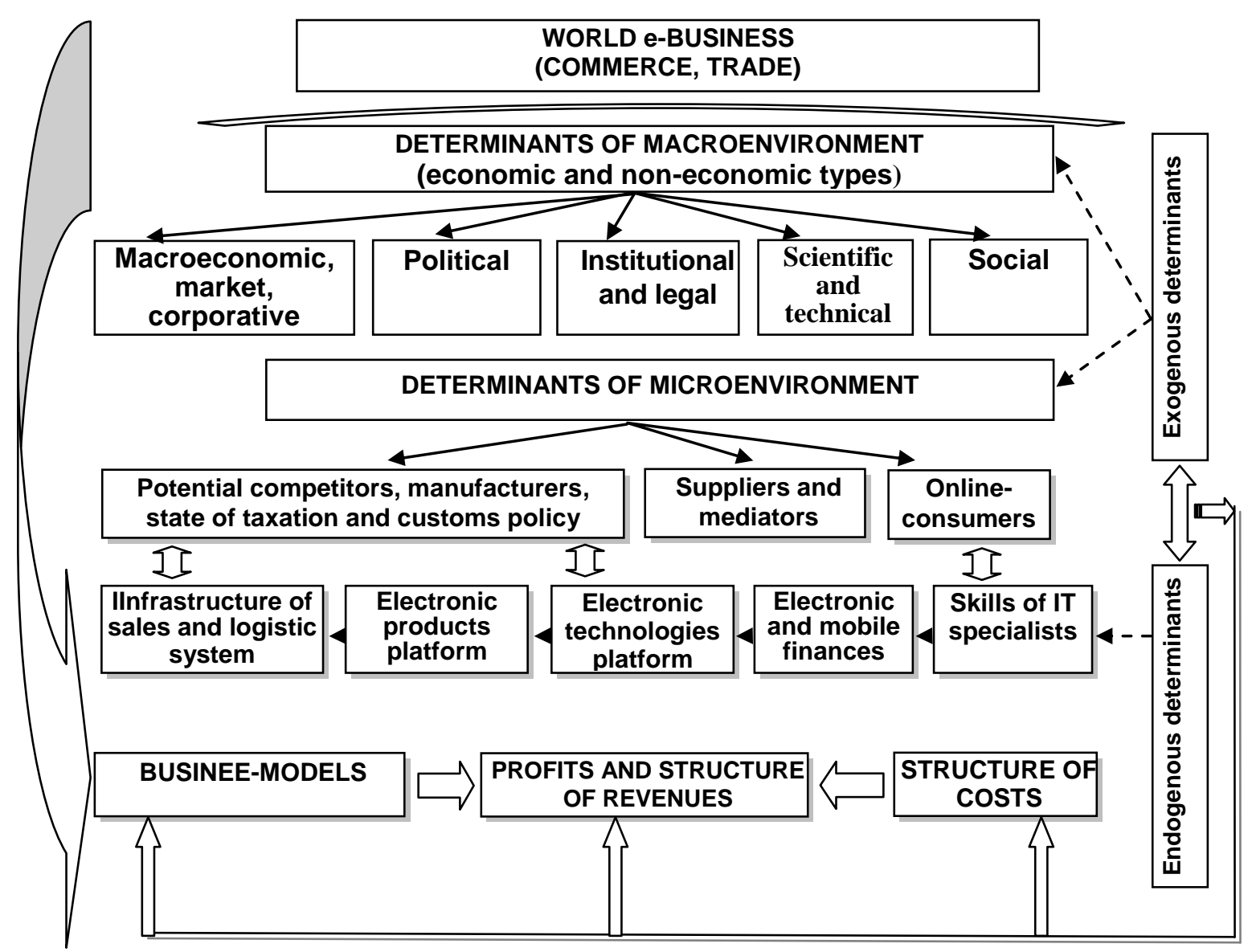

Fig. 1. Structure of key determinants affecting the functioning of world electronic business (commerce, trade). Source: developed by the author.

On the whole we share the opinion of A. Mazaraki and T. Mel'nyk that concerns their analysis of M. Porter's theoretical studies [24, pages 5-17]. Analyzing his conclusions about the concept of national competitive advantages the scientists illustrate it by an imaginary structure in the form of "the national diamond" whose vertexes are four determinants: competition for intellectual and finance capital, competition among various kinds of telecommunications; intellectual resources, information technologies; demand for information products from businesses, non-commercial institutions, households; supporting industries and 
infrastructure. In addition to the factor conditions specified in the model of comparative advantages $M$. Porter added two additional ones to the first determinant: the scientific and information potential that embraces all knowledge (scientific, technical, market etc.) accumulated in the country and the infrastructure (market, education, social and cultural etc.). Among them the scientists single out the most developed knowledge which is generated and permanently developed due to creative efforts of highly qualified specialists.

M. Porter attributed invention, significant technological breaks-through, sharp changes in prices for resources, situation changes on the world financial markets to the incidental determinants. Some of them can result in cardinal changes in the company's positions reducing their advantages and the level of competitiveness [24, pages 5-17; 36; 52, pages 127-128].

In our opinion these determinants by M. Porter (individually or all together as a system) initiate an environment in which e-commerce businesses are formed and acted and which have maximum chances for success in those industries or their sectors where the components of the national "diamond" are mutually strengthened. That is each determinant affects all others.

The term "globalized determination" may be interpreted differently as a separate philosophic category that represents the interaction of various global phenomena of the objective reality. In our opinion the use of this concept in scientific studies of international ecommerce has a future and is innovative in the theory of economics.

Under the influence of modern globalized determinants of development related to the processes of establishment of the economy of postindustrial type and accelerated informatization of the world economy significant and totally new positive changes occur in the development of international e-commerce. According to Aad Weening, head of the research center of Interactive Media Retail Group the development of e-commerce markets in Europe and other countries is directly connected with rapidly growing economies or their economic problems. In particular, he said, -'The future electronic retail commerce will be global. If the development of a market in one country becomes slower it can put the brakes on the development of a market on a whole continent and even in the world. We observe a high level of growing confidence in online purchases. In the developed countries electronic commerce is actually supported by their governments and those governments that dare to do such steps act wisely and rightly. The Internet becomes an integral part of the economy of any country and this fact cannot be ignored." [20].

According to $\mathrm{O}$. Romanenko, under the conditions of development of global informatization the following determinants may be singled out among many others that define Internet communication potentiality: high speed of data transmission in the "transparent" (without borders) space; hypermedia presentation of information and significant rates of growth of the number of users; wide possibilities of distribution of information; personal character of communications; information is an object of active interactions between a sender and a receiver on the basis of navigation; permanent dialogue of the "one with one" type is transformed into the "one with many" and "many with many" types; at the same time every user can be both a sender and a recipient of information; information exchange has a form of dialogue; high degree of geographical penetration and unique possibilities of feedback on the basis of interactivity [31, pages 167-173]. In our opinion these factors (without any doubts) directly affect the future development of e-commerce. Nevertheless the new determinants of development of electronic commerce markets demand totally new approaches and methods for implementation of unique possibilities ensured by the worldwide network. Taking into account the difficulties in establishing the above-mentioned factors, which determine processes in international e-commerce within the new global trends and changes, and in the context of informatization of the world economy it is also important to trace the impact of globalization processes on some most significant determinants. In particular, researchers of the European fund of e-commerce (Ecommerce-Europe.eu) forecast that up to 2020 some 
global trade platforms of retail e-commerce of world level (e.g. Amazon (the USA) and Alibaba (China)) will have a share of about 40 per cent of the world market of online retail trade. This indicates the growing impact of global marketplaces on international e-commerce. It should be noted that the Fund's employees have performed this research for assisting participants in e-commerce in establishing their competition strategies on the market where the global trade platforms become a new dominant force. According to the research data obtained by Payvision, the payment company (as on 2015) 70 per cent of large Internet shops in the world are interested in the development of international e-commerce [3;54].

It is also important to study negative problematic phenomena and processes which are the factors of the modern system of international e-commerce development. Thus, taking into account dynamism of environment the need of studies of new factors, forms, preconditions and parameters of the development of export-oriented businesses of economic entities among the participants of international e-commerce. Some aspects of conflict-generating nature which destabilize some determinants of the national systems of e-commerce have influence on occurrence of some insignificant crisis phenomena within international e-commerce. This results in biased attitudes of online buyers to global changes in the Internet and e-commerce. The major feature of these determinants becomes apparent in analysis and accumulation of the proper production factors for economic entities of international e-commerce for the purpose of improving trade collaboration over the Internet.

The virtual space becomes the most important tool of mass trade communications with the aim to represent information transmission processes, exert influence on economic entities of international e-commerce and ensure them the bilateral or multilateral regime of communicative interactions with the use of Internet-technologies and implementation of communication potential. Just the communication potential of the Internet creates advantages for both sellers and potential buyers - opportunity of increased rate of turnover and operative reaction for variable conditions of electronic markets. Hence a scientific problem of identification of major components (determinants), which in their totality form the communication potential of the Internet, emerges. Just this international potential ensures significant advantages for both online sellers and potential online buyers. Under these conditions the necessity of identification of the most important determinants which form the communication potential of the Internet and create new opportunities for interactions between partners in market relations has emerged. In his day E, Giddens, the English sociologist, reasonably asserted "the modern world depends on ceaseless communications or interactions between people who are far from each other" [8, pages 414-415].

Today the globalization is at critical turning point when the growing flows of data and information have a higher economic value than the global products trade. In the report of McKinsey, the competent research institution, "Digital globalization: a new era of global flows" experts James Manika and Susan Lund consider the trends of transborder exchange of goods, services, finances, people, data and information. According to their forecasts transborder flows of data are anticipated to grow by a factor of nine (9) up to 2020; about 1 billion of buyers will spend 1 trillion USD within the scope of international trade; now there are about 50 million of small and medium enterprises (SME) which join the global social media and 10 million SMEs carry out the production operations at the e-commerce web-site Alibaba (China) and 2 million SMEs - at Amazon [42]. According to eMarketer, the international research company, now the cumulative rates of retail sales slow down but revenues from e-commerce sales are booming. According to the forecasts until 2020 the total world volume of retail sales over the Internet will be 4058 billion USD, that is 14,6 per cent of all expenditures on convenience goods of the world population [55].

Thus, the scale of coverage by world e-commerce, the depth of its penetration, the variety of its effects on open economies, the national features and transborder opportunities have clearly demonstrated to the mankind that a new global information configuration of world economy and international trade is gradually taking place now. In this process, which 
A. Toffler prophetically characterized as "superstruggle of the tomorrow" between adherents of industrial and information societies, the information factor acquires the importance of "...the most important resource of the Era of power transformation" [35, page 202].

In our opinion, the main elements of international e-commerce in the global economy gradually acquire totally new features and factors, which are not appropriate for the traditional off-line trade, and this process is caused by wide informatization of production and turnover processes and specificity of online information products and services. In particular, on this occasion Manuel Castells, the researcher of information (postindustrial) societies, noted that new economic forms are constructed on the basis of global network structures of capital, management and information and now the access to technological knowledge and know-how acquired in these networks is a basis of productivity and competitiveness. Companies and firms are united in various network configurations in a greater degree than other organizations and institutions. The structure of these configurations signifies a deviation from traditional differences between large corporations and small businesses and covers sectors and business groups organized according to the geographic principle. Under these conditions the informatization factor is among the fundamentals.

M. Castells defines the economy of a new type as global and informative. The economy is informative because "... productivity and competitiveness of factors or agents of this economy depend on their ability to generate, process and apply information based on knowledge". In M. Castells' opinion the economy is global because "... the main types of economic activities such as production, consumption and circulation of goods and services as well as their components (capital, labor, raw materials, management, information, technologies, markets) are organized directly or with the use of an extensive network that connects economic entities" [16, pages 39, 81; 17, pages 494-505].

Other American researcher, the author of the concept of creation of the information society, Peter Drucker stated that for the information revolution e-commerce has become the same as the railroads were for the industry: a totally new, unprecedented and unexpected circumstance. However any local companies or definite geographical opens do not exist for ecommerce. This cardinally changes economies, markets and industry structures, products, services and their flows, segmentation of consumer markets, consumer values and consumer's behavior as well as jobs and labor markets [12].

In our opinion, now many interrelated factors affect the development of international ecommerce with both positive and negative consequences. Criteria for classification of certain factors such as basic and advanced, general and specific shall be considered dynamically as they are time-dependent. The task of studying and systematization of these factors is rather complicated but its solution will allow us to determine strong and weak sides of international e-commerce, develop measures for improving efficiency of worldwide competitiveness of this type of commerce under conditions of crisis phenomena. During establishing an economic and organizational mechanism for functioning international e-commerce the need in analysis of some factors affecting its efficiency arises.

Some factors have performed functions of the main driving force of the dynamic development of international e-commerce, in particular, the transition from the postindustrial society to the society of consumption with clear reorientation to various and growing demands of online consumers. The continued global development of information and communications technologies as well as scientific and technological advance has assisted the development of modern information and telecommunication technologies that are universal by their nature. They expand their influence not only over e-services trade but become a basis for production of many nonmaterial products, significantly reduce time losses in the global information space, become key factors that ensure rapidity of making decisions, transmission of information, opportunities for cooperation and e-commerce development, formation of new competitive advantages, further strengthening the role of e-services as an impact factor for efficiency and competitiveness, development of the national systems of information society. 
Among the scientific and technological and innovation and globalization determinants that affect the development of international e-commerce the growth of mobile and multichannel commerce should be singled out. According to the experts' evaluations "the explosive rate of growth" of mobile commerce used in the international trade increases from 57 per cent in 2014 to 79 per cent in 2015 [3]. As M. Porter noted, "Technological changes are increasingly considered as ones that possess inherent values and any technological innovation implemented by the company is considered as a positive factor" [51, page 132].

The today development of the world economic knowledge, according to Ukrainian scientists S. Sidenko and O. Stadnik, implies a new degree of importance of technologies and innovations at both national and international levels. Innovations in the form of intellectual property objects being one of the defining development factors of the world economy and trade also become an economically important asset such as labor or capital and are an object of trade relations between residents of various countries.

In this context let's consider the factors of intellectual property more particularly. As a matter of fact international e-commerce in objects of intellectual property is a transfer of rights to new knowledge. The term "transfer of rights" means consent of the owner of all exclusive rights for intellectual property and acquisition of these rights by the buyer irrespective of his status as a natural or legal person. According to "Handbook of international trade statistics" jointly developed by the UN and IMF all transactions with intellectual property objects may be related to trade of services or operations with capital. Expanded international practices of trading in the Internet-services significantly complicate the ways for improvement of the current mechanisms of protection of intellectual property rights. Taking into account the factor of information globalization such an improvement shall be implemented by harmonization of laws, improvement of functioning of transnational institutions and development of new techniques o evaluation of intellectual property objects [34, pages 4-7].

There are a number of problems that concern with performing international e-commerce in compliance with the rights to intellectual property objects. In the first, electronic piracy remains the actual problem due to easiness of making ideal digital copies of books, photos, music pieces and films and efficacy of their distribution across the international systems of ecommerce. In the second, when any protected object of intellectual property is placed at the Internet network the authors do not control accessibility to this information. Since the number of sold copies may be accurately determined for traditional media but in a case of a network only one copy may be sold. If a license to use the object of intellectual property is bought from the author and placed at the network it becomes available to all. The share of commercial operations over the Internet, which ensure protection of author or patent rights, is only 25 per cent of their total number. Thus, an increase in non-controlled e-commerce with intellectual property objects, level of piracy with respect to objects of author rights, distribution of counterfeit products, and activation of plagiarism are observed. The practice shows that the most part of infringements in the Internet is related to the intellectual property rights to trade marks, less frequent are unlawful use of others commercial names and geographical directions [4, pages 35-40; 10, pages 153-165].

Thus, in our opinion, it is important to apply new approaches to facilitate solving the urgent problems of e-commerce development in the sphere of intellectual properties:

- regulate the use of domain names which allow identification of persons who produce goods or providers of e-services within the scope of World Intellectual Property Organization (WIPO) by means of elimination of contradictions between the system of their names and the rights of intellectual property;

- enlarge participation of countries in the international cooperation in developing practices for protection of rights for intellectual property objects in the Internet environment and regulate online procedures of submission and processing of international applications within the scope of WIPO; 
- increase responsibility of providers on online services in the sphere of intellectual property.

The practical opportunity to use a unique mechanism of tax-free e-commerce from offshore zones has led international Internet-retailers to establish transborder sales channels, register legal persons in neighboring countries and sales goods from abroad directly to natural persons reducing their expenditures on payments for import VAT. customs, certification and other overhead costs. These issues have become the object of detailed studies by representatives of countries-members of G20 and OECD. On the basis of the results of the joined efforts of international working groups "Plan on measures against erosion of taxation bases and removal of profits from taxation" has been approved and in 2016 it was agreed with 83 countries. This plan proposes a global redistribution of VAT between budgets of various countries for preservation of the principle of fair taxation in the sphere of international ecommerce. As due to flaws in the regulations for taxation of this type of trade large multinational companies have obtained a possibility to use advantages of the offshore trade where the most effective solution, which can level the conditions of business operations for foreign and national companies, is collection of VAT from every delivery of goods at the place of generation of profits (a place where goods or services are consumed), or implementation of the national unified electronic system for proper VAT-registration of all foreign e-shops (on the British model). Therefore, in our opinion it is important to apply the same approach to e-services rendered remotely and realization of e-content [11, pages $92-$ 95].

Today the gradual modification of existing factors and occurrence of totally new factors take place. These factors affect volumes of demanded and proposed goods and services via international systems of e-commerce, reduction of transaction costs, domination of price competition at electronic markets. In particular, in 2017 the Zebra Technologies company published their study under the name "2017 Retail Vision Study". This large-scale study was devoted to global process trends that significantly improve the retail industry and systems used to evaluate quality of customer servicing. According to the obtained results about 70 per sent of the participants who make decisions in the sphere of retail sales are ready to begin operations with innovative technologies on the basis of Internet goods until 2021 and 65 per cent plan investments into a technology of automation of warehouse inventory and presentation of goods. According to the experts' forecasts until 2025 the market of Internet goods will exceed the current volumes of global e-commerce by several fold and amount to 8 trillion USD. It will promote a fast growth of delivery, transportation and warehousing services all over the world, Logistic companies will be obliged to provide for flows of automatic orders of Internet goods which will ensure them about 1,9 trillion USD annually in profits. Until 202 there will be 50 billion of devices connected to the network in the world [27;37].

Among new important social-economic and financial-globalized determinants which directly affect the development of international e-commerce the current state and forecast of development of this kind of trade within the known social networks is the first to be considered as they are characterized by large-scale implementation of network forms of organization of business activities. According to the statement of American scientist M. Jackson, now on the many countries social networks cover more and more spheres of economic life and their importance for information floes exchange, carrying out business, trading in goods and services permanently increases [46, pages 17].

Impact of this factor may be traced in the following sequence: from simple forms of social network integration with sites of e-shops (access through the social networks, widgets, likes i shares) to socialization of e-shops themselves and utilization of data obtained in social networks for personalization of online-buyers. It shall be noted that e-commerce has gained some development in the system of classic social networks, in particular, from direct sales (at the sites of these networks or additions to e-shops) to direct integration of global marketplaces 
such as Amazon, eBay, Alibaba in the social networks (i.e. with Google, Facebook, Twitter, LinkedIn). It is also should be noted that until 2020 the share of marketplaces in international e-commerce will be about 40 per cent. In the opinion of Jorij Abraham, Research \& Advice Director at the Netherland E-commerce Foundation, e-commerce global platforms can significantly increase domestic and international sales of retailers and brands, by helping them to reach more customers. It has been established that 62 per cent of retailers in the world have e-shop (in the Netherland - 76 per cent). There are 70 per cent of such sellers in Britain, but only 48 per cent - in France. Only 20 per cent of retailers in the countries, where the study was carried out, can show a mobile addition to their e-shops. Such sellers actively record a positive effect of e-commerce on the level of sales and 75 per cent of them expect a more rapid growth of future sales. Sixty (60) per cent are sure that retailers who do not invest into e-commerce will meet serious problems in near future. The most part of them consider that the key to success is availability of both real shop and e-shop. According to data of the annual research into e-commerce (Global Online Shopping Study) the buyers from South Korea (21 $\%)$, China (21\%), India (15\%), and Japan (15\%) consider that purchases shall be mainly made at national e-shops. On the contrary the residents of Australia (63\%), Canada (54\%) and Russia (54\%) seek to order goods at foreign Internet-retailers. According the data of this research high costs of delivery (68 per cent of buyers), additional payments during receipt of goods such s customs duties and taxes (58\%) and time of waiting of deliveries (42\%). Only 46 per cent of respondents consider purchases in foreign e-shops as completely safe. Sixty eight (68) per cent of respondents are ready to make purchases abroad because it allows them to save money [44; pages 45,$47 ; 29 ; 40]$.

According to the research of the international analytical agency Forrester Research, in which more than 13000 buyers from 7 European countries took part, until the end of 20253 per cent of retail sales in Europe will be made over the Internet. The data showed that online traffic of mobile gadgets very quickly moves to the turning point when mobile purchases in EU countries come to 50 per cent of online sales. Before the end of 2020 five main categories of product groups will amount more than a half of the total volume of cross-channel sales in particular the following: garden and home improvement, cosmetics, jewelry and watches, clothes and footwear. In the experts' opinion, until 2020 the total volume of cross-channel retail sales in Europe will amount 704 billion euros that is by 247 billion more as against 2015. Taking into account the cross-channel sales together with the online sales the total volume will increase up to 947 billion euros that is 53 per cent of all European retail sales. At that, the UK will have the most share of sales over the Internet [49]. Nevertheless, despite the fast growth of e-commerce such as in EU countries on the beginning of 2016 there were only 12 per cent of participants who exported goods to other countries over the Internet due to high costs of shipping transborder deliveries. At the same time, according to the recent research B2C Europe, in which the behavior of online consumers in 8 countries of the euro area was analyzed, 37 per cent of retail trade enterprises sale goods over the Internet in their own countries. The main obstacle to trade over the Internet sector is a fact that the abovementioned costs may be five times as the costs of domestic transactions in every EU country. In addition, only 15 per cent of consumers make purchases over the Internet in other EU countries but 44 per cent spend money at online shops in their countries. These data convince that the international logistics related to e-commerce shall be considered as a key factor of development of the world economy informatization and international e-commerce. The highproduction logistic environment stimulates the country's ability to competition. For example, the role of mail logistics for e-commerce is to create a system that ensures deliveries of parcels with ordered goods within the terms agreed with the customer, obtaining information about the progress of delivery of orders via the tracking system, prompt returning of goods, taking charge of safety of investments, making deliveries in accordance with the acceptable rates and providing the financial efficiency of the participants in the process. Now 40 per cent of Europeans reject purchases over the Internet due to high costs of delivery and additional 20 
per cent due to lack of an acceptable for them way of payment. Long time of waiting of goods is also a cause of 15 per cent of refusals, non-availability of rules of return of goods accounts 11 per cent of refusals of online purchases. Thus, in the near future solving the above problems in international e-commerce among some EU countries will depend on quality of logistic management $[13 ; 43 ; 47 ; 48]$.

Economic entities shall consider the specified factors and trends upon making decisions on production, exchange, distribution and consumption of information and network goods (services) for the purpose of improvement of their utilization. According to the conclusion made by A. Suvorov, head of department of IBM EE/A corporative systems, on the basis of the research performed by IBM, in which about 1700 top managers of IT companies from 64 countries and 18 industries took parts, within the next 3-5 years the ICTs will become the strongest catalyst of organizational changes that the economic factors [7].

To find the features of e-commerce markets and factors that affect their development the largest private consulting institution Cushman \& Wakefield published a report "Global Perspective on Retail" in which the volumes of retail trade and infrastructure were compared for the more than 100 countries of the world. In general, this report comprises an analysis of the international e-commerce market, evaluation of infrastructure, legal and regulatory frameworks and sizes of retail and e-commerce markets. Weighed indices on the basis of thirteen indicators which are used for determination of the level of development of ecommerce have been calculated for each country [26].

Therefore it makes sense to consider some indicators and positions of the authors and experts of this research consistently.

One of the authors, John Strachan, head of international services at Cushman \& Wakefield (the USA) considers that the Internet has cardinally changed the picture of global retail trade and continues to exert no less influence on the way by which we make purchases. If retailers and developers will promptly adapt themselves to new conditions they can achieve not only a significant rise in sales but also strengthen the positions of traditional shops and business centers. The other participants of the research, Matt Winn, head of retail property at Cushman \& Wakefield consider e-commerce as a global phenomenon that has its specific features related primarily to economy, culture, legal and infrastructure systems in various countries. All this factors affect not only the real trade industry but also the volumes of online sales. The researcher James Hawkey, managing director of retail property in Asia at Cushman \& Wakefield, is convinced that e-commerce has a necessary potential to change totally the pattern (for example) of international retail trade. Now the brands which want to come to Asia can firstly "sound out" the market by opening e-shop and only then open real ones. David Hutchings, head of EMEA research at Cushman \& Wakefield is convinced that combination of online and offline trades may be a significant factor and competitive advantage for retailers and business centers in the world. In this case e-commerce will facilitate personalization of services for customers and at the same time e-shops in business centers will availability and direct interactions between the brand and customers. He also concluded that e-commerce significantly changes a pattern of costs and this finally affect demands for real property [26].

"In prospect, the success of companies that operate at already established growing markets will depend on such factors as innovation development of all points of contacts with customers, in-depth analysis of causes that motivate customers to make purchases over the Internet and do not use other channels, as well as clear understanding of consumer expectations from the stage of ordering to the stage of delivering of goods," - considers Parvaneh Nilforoushan, consultant at AT Kearney. In particular the world largest marketplace of e-commerce Amazon.com (hereinafter "Amazon") will be the first company with market capitalization in the amount of 1 trillion USD. This was stated by Scott Galloway, professor at the New York University, the founder of L2 Inc., the service of intellectual business-analytics. According to him, too many retail shops are operated in the USA and therefore in near future the situation will change. "The most part of retailers will face a threat of stagnation of middle 
class wages and departure from typical retail goods. The USA may lose one third of shops but we will not notice their disappearance. This will be beneficial for customers and shareholders of Amazon, but the global ecosystem, which comprises 11 million cashiers, will be the loser", - said Scott Galloway. The expert admits that the company can increase annual expenditures of households from 1300 USD to more that 7000. Due to this Amazon outranks such companies as Google and Apple and attains such a high level of capitalization. In spite of an early phase of occurrence of "shops of future" professor Galloway takes note of an announcement of "Amazon Go" - shops without cashiers". "May be three of eleven million cashiers in the USA have been signed off at this day. Simply they do not still know about this. In our country there are more cashiers than teachers. I frequently communicate with retailers who use a term "optimization" but its real meaning is "dismissal of employees" [9; pages 41, 47].

In our opinion, any optimization of personnel shall take into account best practices. For example, In China the factors that affect creation of jobs are priority. According to the report of BCG consulting company, until 2035 the giant of e-commerce, Alibaba will create 122 of 415 million $(29,4 \%)$ jobs by opening their own factories, construction of housing habitation and others in the Chinese IT industry. According to the data of the Chinese People University, only one platform of Alibaba e-commerce created 31 million jobs in the beginning of 2017. In addition, the company put into operation 15000 tao-factories (mini-production facilities which allow the sellers registered at site Taobao to produce small lots of goods). It also has opened 1300 villages Taobao which become centers of e-commerce in rural areas. According BCG data, until 2035 the IT industry in total will amount 48 per cent of the national economy and its calculated turnover will be 16 trillion USD. It should be noted that in 2015 it was only 13 per cent of the general indices of the China's economy and its calculated volume was 1,4 trillion USD and 100 million jobs were created. It is expected than until 2025 the country's IT economy will create more than 400 million jobs [1].

In 2016 PayPal company presented the third annual global report on development of international e-commerce. During its preparation 28000 online consumers from 32 countries were interviewed (how and why they participate in e-commerce, including at foreign sites) [50, page 22]. This research revealed a number of factors that can have both positive and negative effects on development of trade activities (Appendix E). The key trends are as follows: for online-buyers from all over the world today China is the most popular country in e-commerce ( $21 \%$ share). Even more: according to the research of the McKinsey Global Institute the online purchases in China are not simple replacements of usual ones: retail ecommerce actively supports additional consumption. For example, 1 USD of online consumption generate about 0,40 USD of additional sales. By now China can easily overtake the USA as to competence of consumers and their skills in spending money. The other countries are as follows: the USA (17\%), the UK (13\%), Germany (7\%), and Japan (4\%). As on the beginning of 2017 about two thirds of all international online purchases were made via Amazon.com, eBay (the USA) and Alibaba (China). The most popular categories of goods are footwear and clothes (33\%), consumer electronics (21\%), books, music and media (14 $\%)$ as well perfume and cosmetics $(13 \%)$. Generally the goods ordered by online consumers are light and inexpensive. Example: 45 per cent of all goods acquired over the Internet network have a mass up to $500 \mathrm{~g}, 16$ per cent of them cost less than 10 euros. Another 40 per cent are within the cost range 10 to 49 euros $[14 ; 22 ; 32$; pages 50, 22].

According to the research of PayPal customers from East Europe are less willing to buy at global online shops than customers from other parts of the world. The key factors of such approach are cost of delivery, a level of taxation and a system of selection of payment options. To buy a thing at foreign e-shop customers shall be seriously interested in it. The main reason of making such a purchase 76 per cent of respondents indicate "good price" and 65 per cent indicate a possibility to buy goods that are not available in their countries. However, when we consider other motivations to make international online purchases and the 
factors that affect a choice of payment option the most important reasons are: free-delivery (46 per cent of interviewed customers) and safety and easiness of a payment option (44 per cent) [ 50, page 22].

In Ukraine the ICT systems and e-commerce market which now are forming as leading facilities of the national production during a long time were developed without any real state support. The role of such a support was reduced to collection of statistical data, random checks of IT sector (quite often unreasonable) which did not reflect the real state of things. Well-founded scientific studies of this sphere, specifically in relation to the EU nearly didn't carry out. The current situation in Ukraine indicates strongly the necessity of immediate increase of the state's impact of the economic processes with the use of a wide range of mechanisms of state regulations. First of all it concerns a system of further improvement of state control over external economic activities (EEA) and customs procedures in context of implementation of European mechanisms and tools. In this regard there are substantial obstacles for further development of EEA including international e-commerce in Ukraine. For example, now the Law of Ukraine "On external economic activities" which was revolutionary 26 years ago does not comply any international practice or laws of the EU to which Ukraine intends to adapt its regulations. This law and by-laws related to it show disorder and often lack of proper regulations over the state supervision in the sphere of EEA and this significantly retards the development of international e-commerce in Ukraine as against the other countries of the world.

With the aim to study principal directions for improving state regulations of ecommerce in Ukraine it is useful to analyze the law of Ukraine "On electronic commerce" (No. 675-VIII of September 03, 2015; hereinafter as "the Law") [29].

In our opinion, the term "electronic commerce" of this Law shall be interpreted more loosely to cover the issues that related to all relations occurring under electronic business activities, contractual and non-contractual. Therefore we do not agree with the authors of the new Law who reduce the concept "electronic commerce" to the variant of ordinary business "... in the sphere of electronic sales and purchases, sales of goods to a buyer by a remote method by means of fulfillment of legal electronic transactions with the use of information and telecommunications systems", where this activity (it should be noted) is not yet aimed to gaining profits. It should be highlighted that the authors "have forgotten" to include the concept "e-services" in the determination of the term "electronic commerce" and consider that e-commerce is carried out only in the sphere "... of sales of goods by a remote method". At the same time, in this Law e-commerce is defined as "relations directed to gaining profits, which occur during fulfillment of legal transactions related to acquisition, change or cancellation of civil rights and liabilities and are made remotely with the use of information and telecommunications systems, and which are resulted in origination of property interest and liabilities" [29].

As to the conclusions of the Chief Scientific Expert Department of the Verkhovna Rada of Ukraine with respect to the draft of this Law, in particular of expert V.M. Shamota, the conclusions stated that the terms "commerce" and "commercial activity" were not actually used in the laws of Ukraine. Based on these conclusions and also on the fact that the most part of the provisions of this draft, according to the evaluation of the expert, is directed at the regulation of conducting e-trade activities V.M. Shamota proposed to the authors of the Law to adjust the name of the draft in particular to replace it by a new name: the law of Ukraine "On electronic trade", and amending its text in accordance with the change, including amendments to its scope. It should be noted that we fully support the view of expert V.M. Shamota as to the name of this Law. However, unfortunately the authors of the new law adopted by the Verkhovna Rada in 2015 fully ignored this conclusion of the experts. In practice it may finally result in legal uncertainties in the conceptual and categorical framework as to the terms: e-trade, e-commerce and e-business [6]. 
According to the evidence of one of the authors of the adopted Law, people's deputy O. Bel'kova admits that the main purpose of this document was to give an impulse to development of e-commerce at the domestic market of Ukraine. The same position is adhered by the known Ukrainian expert, president of the investment holding Internet Invest Group O. Ol'shanskyi who persists that a sole chance for the new Law to be adopted at all was to make it highly specialized. Otherwise it will be never adopted [15].

In our opinion, the main deficiency of the Law is also its scope of applications because it only regulates the mechanisms of development of domestic (national) e-commerce (e-trade) and does not provide for development of international e-commerce (there is no any corresponding section). It will not facilitate the efforts of a wide range of Ukrainian exporters, other participants of business relations between countries under conditions of functioning of the deep and overall free trade area between Ukraine and the EU countries (from 2016).

At the same time Ukraine, despite the progressive positive trade trend in 2017 as against 2016, worsened its position the World Bank's rating "Doing Business" by 5 positions and took 115 rating position in the category "international commerce". Under this category the complex evaluation is made by time and costs which are required for export-import procedures including execution of documents and customs and border checks. In addition, the country's business reputation is evaluated by its partners by many factors, in particular, freedom of trade (capital and goods flows, transparency of procedures, stability of laws) [18 ].

In our opinion, the method of PESTLE analysis is more effective for analysis of microenvironment factors and their impact on the external economic activities of some economic entities of international e-commerce. This method has been actively developed during the last ten years as an analytical tool of strategic planning. Its aim is to determine the effect of factors of political, economic, sociological, technological, and legal natures as well as the environmental factors [53, pages 384-388].

Every type of the PESTLE analysis may be used in accordance with the aims and the purpose of the study of factors effects, for example, the effect on activities of some economic entities of e-commerce. In addition, this method gives an opportunity of developing a strategic business plan for development of such commerce. To carry out the analysis one shall firstly determine factors that affect the international activities of the subjects of e-commerce, evaluate their potential impact, possible manifestations and importance. In our opinion, such factors may be the following: the state's customs and fiscal policy, demand for products in a foreign market, exchange rate of the national currency, level of inflation, mobility of population, level of development of innovations in the industry, state of antimonopoly and labor laws, activities of regulatory authorities. Accordingly, the factors are finally distributed into political, economic, sociological, technological, legal and environmental groups.

To determine a weight coefficient for every factor one shall evaluate a degree of its effect on international activities of every economic entity of e-commerce. This can be done with the use of the 3 point scale (1 point - change of factor does not affect international business; 2 - significant effect of change of factor; 3 - strong effect of change of factor); carry out the expert evaluation of probability of changes for every factor with the use of the 5 point scale (5 points - high probability of changes, 1 point - low probability of changes) and calculate the average values of expert estimates. Accordingly, the weight coefficient for every factor is calculated by formula:

$$
K f=C \exp \times(B f / Z f)
$$

The complex where $K f$ is the weight coefficient of the factor;

Cexp is the average value of the expert estimates;

$B f \quad$ is the effect of the factor;

$Z f \quad$ is the total sum of points of the effect of the factor. 
typology of the microenvironmental factors that affect the international activities of subjects of e-commerce may be also classified in Table 1 [25, pages 63-66; 50].

Table 1

\section{FACTORS THAT AFFECT POSITIVELY OR NEGATIVELY ON DEVELOPMENT OF INTERNATIONAL ELECTRONIC COMMERCE (AS ON THE YEAR OF 2016)}

\begin{tabular}{|c|c|}
\hline Factors & $\begin{array}{c}\text { at } \% \\
\text { persons }\end{array}$ \\
\hline \multicolumn{2}{|l|}{ Top 5 reasons of refusal of transborder purchases } \\
\hline - cost of delivery & $35 \%$ \\
\hline - fears of non-receipt of ordered goods & $33 \%$ \\
\hline - taxes / charges & $30 \%$ \\
\hline - speed of delivery is not sufficiently high & $29 \%$ \\
\hline - fears of discrepancy between appearance of goods and its description & $29 \%$ \\
\hline \multicolumn{2}{|l|}{ Top 5 reasons of making transborder purchases } \\
\hline - better prices & $76 \%$ \\
\hline - availability of goods which are absent in my country & $65 \%$ \\
\hline - availability of new and attractive goods & $59 \%$ \\
\hline - variety of goods and styles at sites of a certain country & $52 \%$ \\
\hline - availability of delivery & $50 \%$ \\
\hline \multicolumn{2}{|c|}{$\begin{array}{l}\text { Main factors that affect the choice of payment options for online purchases at foreign onlin } \\
\text { shops }\end{array}$} \\
\hline - safety of purchases & $53 \%$ \\
\hline - convenience of purchasing & $44 \%$ \\
\hline - payments are accepted by the most part of online sellers & $41 \%$ \\
\hline - fast handling of payments & $37 \%$ \\
\hline - known brand & $34 \%$ \\
\hline - no requirement to share personal or payment information with a seller & $31 \%$ \\
\hline - protection of purchased goods & $30 \%$ \\
\hline - fast process of purchase registration & $30 \%$ \\
\hline - price for purchased goods which is indicated in the national currency & $25 \%$ \\
\hline - practices of online buyers & $20 \%$ \\
\hline
\end{tabular}

Source: developed by the authors on the basis of [50].

In such a way practical results of the applied PESTLE analysis of factors that affect the development of international business of specific economic entity of e-commerce may be presented in an integrated fashion by means of determination of a weight coefficient for each factor [33, pages 38-50]. 
Conclusions. The nature, preconditions and factors of growth that determine the formation of the determinants of development of the sphere of global functioning of ecommerce. The main macroeconomic factors have been defined and the dependence of the factors of e-commerce development on the key determinants of the process of formation and utilization of the strategic potential of current transformations of e-commerce economic activities has been studied. The analysis has shown the necessity of complex evaluation of the state and trends of investment climate in Ukraine with the use of statistical analytical tools and harmonization of qualitative and quantitative components of the model for evaluation of investment appeal of Ukraine and the EU countries. The performed empirical analysis and obtained results may facilitate further studies for finding and adopting reasonable solutions for improving the investment image of Ukraine and increasing the volume of attracted foreign investments and capital investments in the national economy. Thus, the described processes resulted in formation of a totally new form of making trade and financial transactions and business processes which mediate them - a virtual one. This form has created a technological basis for development of international e-commerce. Under conditions of global informatization of goods and services flows specific nonprice determinants of demand and proposition of network goods and services are generated. sustained reduction of costs for search, processing and keeping information about prices, goods, manufacturers, suppliers and consumers facilitates more effective formation of equilibrium prices as well as increased transparency of markets and world competition. Global reach of environment is evident as a large-scale nature of the Internet and ICT which provide access to foreign e-markets of global importance at minimum costs for economic entities. Under these conditions the leading industries of the information networked economy create the corresponding e-sectors of the global economy without borders: e- (electronic and m-mobile) commerce and finances, telecommunications sector and IT, electronic media.

\section{References}

1. Alibaba stvorit $30 \%$ robochikh mists v tsifroviy ekonomitsi Kitayu / Fi.Novini: inform. resurs. 18.04.2017. URL: http://news.finance.ua/ua/news/-/399637/alibaba-stvoryt-30robochyh-mists-v-tsyfrovij-ekonomitsi-kytayu.

2. Belova O.I. Determinanti motivatsiynogo mekhanizmu strategichnogo upravlinnya $\mathrm{v}$ torgovelnikh merezhakh: klasifikatsiya ta osoblivosti. Innovatsiyna ekonomika. 2013. № 6(44). S. 235-241.

3. Bolshinstvo internet-magazinov zainteresovany v mezhdunarodnoy torgovle / PAI Spase Magazine. 20.10.2015. URL: http://psm7.com/most-online-stores-are-interested-ininternational-trade.html.

4. Valkovets A.S., Yuskovich-Zhukovska V.I. Vpliv intelektualnoï vlasnosti na elektronnu komertsiyu. Visnik Natsionalnogo universitetu vodnogo gospodarstva ta prirodokoristuvannya. Seriya «Yekonomika». 2012. № 3(59). S. 35-40.

5. Velikiy tlumachniy slovnik suchasnoï ukraïnskoï movi (z dod. i dopov.) / uklad. i golov. red. V.T. Busel. Kiïv; Irpin : VTF «Perun», 2005. 1728 s.

6. Visnovok na proekt Zakonu Ukraïni «Pro elektronnu komertsiyu» (reestr. № 2306a vid 17.06.2013 r., vneseniy narodnimi deputatami Ukraïni O.V.Bєlkovoyu, N.V.Agafonovoyu, O.M.Rizhenkovim ta in.) [Yelektronniy resurs]. - Rezhim dostupu: http://w1.c1.rada.gov.ua/pls/zweb2/webproc4_1?pf3511=52409.

7. Voronin A. IBM: tekhnologii budut izmenyat biznes silnee, chem ekonomika / PC Week/RE. 27.03.2013. URL: http://www.pcweek.ru/idea/article/detail.php?ID=148844.

8. Giddens E. Ustroenie obshchestva: Ocherk teorii strukturatsii. M. : Akademicheskiy proekt, 2003. $528 \mathrm{~s}$.

9. Demchenko D. Amazon stanet pervoy kompaniey s kapitalizatsiey v $\$ 1$ trln / AIN: internet-zhurnal. 14.06.2017. URL: https://ain.ua/2017/06/14/mnenie-amazon-stanetpervoj-kompaniej-s-kapitalizaciej-v-1-trln. 
10. Dmitrieva N.O. Mizhnarodniy dosvid u virishenni problem informatsiynoï bezpeki elektronnoï torgivli. Zovnishnya torgivlya: ekonomika, finansi, pravo. 2010. № 2. S. 153-165.

11. Dmitrieva N.O. Perspektivni napryami opodatkuvannya mizhnarodnoï elektronnoï torgivli v Ukraïni. Vikliki globalizatsiï KhKhI st. ta strategiya sotsialno-ekonomichnogo vidrodzhennya Ukraïni : mater. Mizhnarodnoï nauk.-prakt. konf. (Kiïv, 24 travnya 2016 r.). K. : KNTYeU, 2016. S. 92-95.

12. Druker P. Za fasadom informatsionnoy revolyutsii / Gumanitarnye tekhnologii: analiticheskiy portal. 10.12.2006. URL: http://gtmarket.ru/laboratory/expertize/4975.

13. Zamedlenie rosta e-commerce v Yevrope vyzvano vysokoy stoimostyu transportirovki / Retail-Loyalty: zhurnal. 15.03.2016. URL: http://www.retailloyalty.org/news/zamedlenie-rosta-e-commerce-v-evrope-vyzvano-vysokoy-stoimostyutransportirovki/.

14. Interesnye fakty ob e-commerce: chto i kak pokupayut v seti? / PaySpace: Magazine. 23.01.2017. URL: http://psm7.com/news/interesnye-fakty-ob-e-commerce-chto-i-kakpokupayut-v-seti.html.

15. Kak otreguliruyut e-commerce. Sem zamechaniy k proektu zakona. [Yelektronniy resurs]. $\quad-\quad$ Rezhim dostupu: http://webcache.googleusercontent.com/search?q=cache:sFQ55LsXQ_UJ:biz.liga.net/all/ it/stati/2646035-kak-otreguliruyut-e-commerce-sem-zamechaniy-k-proektuzakona.htm $+\& \mathrm{~cd}=52 \& \mathrm{hl}=\mathrm{ru} \& \mathrm{ct}=\mathrm{clnk} \& \mathrm{gl}=\mathrm{ua}$.

16. Kastels M. Informatsionnaya epokha: ekonomika, obshchestvo i kultura / pod. nauch. red. O.I. Shkaratana. M. : GU-VShE, 2000. 606 s.

17. Kastels M. Stanovlenie obshchestva setevykh struktur // Novaya postindustrialnaya volna na Zapade : antologiya / pod red. V.L. Inozemtseva. M. : Academia 1999. S. 494-505.

18. Korotka T. Zmastit kolesa mizhnarodniy torgivli / NV: Biznes. 9 chervnya 2017. URL: http://biz.nv.ua/ukr/experts/korotka/zmastit-kolesa-mizhnarodnij-torgivli-1287582.html.

19. Kramorenko N.R. Suchasni determinanti elektronnoï komertsiï v segmenti V2V. Formuvannya rinkovoï ekonomiki. 2010. № 23. S. 351-359.

20. Kratkiy obzor rynka elektronnoy kommertsii v mire / Ye-business: informatsionnyy biznes-portal. 16.06.2012. URL: http://elbusiness.ucoz.ru/news/kratkij_obzor_rynka_ehlektronnoj_kommercii_v_mire/2012-0616-56.

21. Kudinova A. Globalni determinanti transformatsiï vidnosin spozhivannya. Tovari ta rinki. 2014. № 1. S. 14-25.

22. Kuper R., Dobs R. Revolyutsiya v sfere elektronnoy roznichnoy torgovli Kitaya. Mysl: zhurnal ukrainskogo isteblishmenta. 2013. № 5(45). URL: http://www.ideamagazine.com.ua/archive/11460/advance/11470.html.

23. Mazaraki A., Melnik T. Determinanti rozvitku zovnishnoï torgivli Ukraïni innovatsiynoyu produktsicyu. Visnik KNTYeU. 2012. № 2. S. 5-20.

24. Mazaraki A., Melnik T. Innovatsiï yak dzherelo strategichnikh konkurentnikh perevag. Visnik KNTYeU. 2010. № 2. S. 5-17.

25. Melnik O.G., Nagirna M.Ya. Diagnostika faktoriv vplivu na eksportnu diyalnist pidpriєmstva. Innovatsiyna ekonomika. 2013. № 5. S. 63-66.

26. Onlayn-torgovlya menyaet geografiyu / Vesti: Ekonomika. 02.07.2013. URL: http://1nnc.net/economics/88579.html.

27. Poka tolko polovina riteylerov torguet $\mathrm{v}$ onlayne / PC Week: informatsionnyy portal. 21.03.2017. URL: https://www.itweek.ru/idea/news-company/detail.php?ID=193417.

28. Poltorak K.A., Zozulov O.V. Suchasniy stan rinku internet-tekhnologiy: determinanti rozvitku rinku ta novi pidkhodi do marketingovoï diyalnosti. Yekonomichniy visnik NTUU «Kiïvskiy politekhnichniy institut». 2015. № 12. S. 372-378. 
29. Pro elektronnu komertsiyu: Zakon Ukraïni vid 25 veresnya 2015 r. № 675-VIII // Zakonodavstvo Ukraïni: ofitsiyniy veb-sayt. URL: http://zakon5.rada.gov.ua/laws/show/675-19.

30. Proekt Mizhnarodnogo Khabu po upravlinnyu proektami stalogo rozvitku / ContentNet : inform. resurs. URL: http://www.c2n.biz/index_biz_new.php.

31. Romanenko O. Determinanti komunikatsiynogo potentsialu Internet. Regionalni aspekti rozvitku produktivnikh sil Ukraïni. 2014. Vip. 19. S. 167-173.

32. Rudaya A. Sem klyuchevykh otlichiy kitayskikh i zapadnykh potrebiteley / IGate: novosti IT-rynka. 14.11.2014. URL: http://igate.com.ua/news/3855-sem-klyuchevyhotlichij-kitajskih-i-zapadnyh-potrebitelej.

33. Semenyuk I.Yu. Otsinka vplivu faktoriv na rozvitok zovnishnoekonomichnoï diyalnosti pidpriєmstv mashinobudivnoï galuzi Ukraïni. Współpraca Europejska. 2017. № 4(23). S. $38-50$.

34. Sidenko S.V., Stadnik O.I. Internatsionalizatsiya intelektualnoï vlasnosti. Naukoviy visnik Institutu mizhnarodnikh vidnosin NAU. 2013. T. 1. № 1. S. 4-7.

35. Toffler E. Tretya volna. M. : Izd-vo AST, 2002. 776 s.

36. Fomichev V.I. Mezhdunarodnaya torgovlya. Teoriya konkurentnykh preimushchestv Maykla Portera / Polka bukinista: internet-biblioteka. URL: http://polbu.ru/fomichev_inttrading/ch09_i.html.

37. Cherez 10 let rynok interneta veshchey dostignet $\$ 8$ trln. / PaySpace: Magazine. 21.04.2015. URL: http://payspacemagazine.com/in-10-years-the-market-of-the-internetof-things-will-reach-8-trillion.html.

38. Shapovalova T.V. Sotsialni merezhi - determinant sotsialnogo kapitalu. Naukoviy visnik: Finansi, banki, investitsiï. 2013. № 3. S. 131-135.

39. Yatsenko O. Globalizatsiyni determinanti rozvitku sirovinnikh rinkiv. Mizhnarodna ekonomichna politika. 2013. № 2(19). S. 66-100.

40. Cross-border ecommerce gains traction; US, UK, Germany - top hotspots: report / The Paypers: Insights into Paypers. 30.10.2014. URL: https://www.thepaypers.com/ecommerce/cross-border-ecommerce-gains-traction-us-ukgermany-top-hotspots-report/757117-25.

41. Deloitte. Global Powers of Retailing 2016 Navigating the new digital divide / Deloitte Touche Tohmatsu Limited. 47 p. URL: http://www2.deloitte.com/content/dam/Deloitte/global/Documents/Consumer-

Business/gx-cb-global-powers-of-retailing-2016.pdf.

42. Digital Globalization: The New Era Of Global Flows / McKinsey Global Institute, 2016. URL: $\quad$ https://www.the-digital-insurer.com/digital-globalization-the-new-era-of-globalflows-mckinsey-report-by-james-manyik-and-susan-lund/

43. E-commerce statistics for individuals: About two thirds of internet users in the EU shopped online in 2016 / European Union: ofitsiyniy veb-sayt CS. Eurostat. December 2017. URL: http://ec.europa.eu/eurostat/statistics-explained/index.php/Ecommerce_statistics_for_individuals.

44. Global marketplaces to own 39\% of online retail market in 2020 / E-Commerce News. June 10, 2015. URL: http://ecommercenews.eu/global-marketplaces-to-own-39-ofonline-retail-market-in-2020/

45. Global Powers of Retailing 2017: the art and science of customers / Deloitte: Global Powers of Retailing report. 47 p. URL: https://www2.deloitte.com/content/dam/Deloitte/global/Documents/consumer-industrialproducts/gx-cip-2017-global-powers-of-retailing.pdf.

46. Jackson M. Social and Economic Networks. Princeton, N. J. ; Woodstock : Princeton University Press, 2008. 544 p.

47. Katzfey R. How to Increase Revenue via International Ecommerce / Multichannel Merchant: online research resource March 30, 2015. URL: 
http://multichannelmerchant.com/global-2/payments/increase-revenue-via-internationalecommerce-30032015/

48. New rules should boost cross-border ecommerce in Europe / Ecommerce News europe. May 26, 2016. URL: http://ecommercenews.eu/new-rules-boost-cross-borderecommerce-europe/

49. Over 50 percent of European retail sales will be influenced by previous online browsing by end of 2020 / The Paypers: Insights into Paypers. 31 July 2015. URL: http://www.thepaypers.com/ecommerce/over-50-percent-of-european-retail-sales-will-beclaimed-by-ecommerce-by-enfd-of-2020/760801-25.

50. PayPal Cross-Border Consumer Research 2016: Global Summary Report / PayPal Inc.. 2016. 22

p. URL: https://www.paypalobjects.com/digitalassets/c/website/marketing/global/shared/global/m edia-resources/documents/passport-citation.pdf.

51. Porter M.E. Competitive Advantage: creating and sustaining superior performance: With a new introduction. New York : Free Press, 1998. 397 r.

52. Porter M.E. The competitive Advantage of Nations. New York : Free Press, 1990. 875 p.

53. Rastogi N., Trivedi M.K. PESTLE technique - a tool to identify external risks in construction projects. International Research Journal of Engineering and Technology. 2016. Vol. 03. Issue 1. R. 384-388.

54. Retailers expect global market places to own nearly $40 \%$ of online retail market in 2020 / FashionUnited. 10 June 2015. URL: http://newsroom.nyenrode.nl/retailers- expectglobal-market-places-to-own-nearly-40-of-online-retail-market-in-2020/.

55. Worldwide retail ecommerce sales will reach $\$ 1.915$ trillion this year / e-Marketer inc.: informatsiyniy veb-sayt. August 22, $2016 . \quad$ URL: https://www.emarketer.com/Article/Worldwide-Retail-Ecommerce-Sales-Will-Reach1915-Trillion-This-Year/1014369. 